Ştefan BAGHIU

Faculty of Letters and Arts, Lucian Blaga University of Sibiu

Sibiu, Romania

stefan.baghiu@ulbsibiu.ro

\title{
TRANSLATIONS OF NOVELS IN THE ROMANIAN CULTURE DURING THE INTERWAR PERIOD AND WWII (1918-1944): A QUANTITATIVE PERSPECTIVE
}

Recommended Citation: Baghiu, Ștefan. "Translations of Novels in the Romanian Culture during the Interwar Period and WWII (1918-1944): A Quantitative Perspective”. Metacritic Journal for Comparative Studies and Theory 7.2 (2021). Doi: https://doi.org/10.24193/mjcst.2021.12.02

Abstract: This article continues the quantitative analysis of translations of novels in Romania for the 1918-1944 period. Baghiu discusses the decay of the French novel (from almost $70 \%$ of the total of translated novels during the long $19^{\text {th }}$ century to almost $43 \%$ during the interwar period), and the case of two competitors in the second line of translations (American and Russian). The article turns then to the European and Global peripheries from the perspective of the colonial '20s and ' 30 , and discusses the eco narratives of the Nordic novel, and the identity function of the Asian novel within this translationscape.

Keywords: Novel, translation, World Literature, quantitative studies, interwar period, Romanian

The interwar period is often described in Romanian literary criticism as a "golden age" of the novel, and the year 1934 has been labeled the "golden year of the interwar Romanian novel" (Cornea 375). While it is true that it really was a golden age for the local production, the number of translated novels sees a significant decrease between WW1 and WW2. This reveals that Romanian literature stops being a minor literature, if 
we are to credit Sean Cotter, who envisions that "the minor is not a failed state or a potentially great one, but a translated nation" (Cotter 2), and that translations fulfilled their accommodation role they were assigned during the long $19^{\text {th }}$ century. As Andrei Terian has shown, the proportions between translated novels and Romanian novels during the 1918-1940 period display a great selfenclosure/enclavization/autochtonization tendency through the "crisis and the boom" (Terian 2019, 62). The Romanian novel soars in the context of the local economic crisis during the ' 30 , yet translations dominate the literary field only after 1940. This is indicative of a special situation, in which crises are responsible for the growth of the local and changes in political administration are responsible for the increase in translations (Baghiu 2021). Of course, the "golden age" of the Romanian novel is also marked by strategies that bolster the introduction of several foreign narrative techniques into the literary discourse, beyond mere translation. The interwar period is known for the rise of modernism, through novels of Anton Holban, Camil Petrescu, and Hortensia Papadat-Bengescu, among many others. At the same time, it was a time in which the social novel enjoyed favorable conditions for growth, as local researchers have recently shown (Terian et al. 54), while minority and feminist narratives gained preeminence through the novels of I. Peltz, Alice Gabrielescu, Cella Serghi, and others. Those writings were mainly driven by a synchronist drive aiming at catching up with the European production of fiction. Yet, they were not always driven by translations. As André Lefevere has shown, translations are only partially responsible for the accommodation of a culture within another:

I would like to turn to the strategy cultures use to let in or keep out prospective imports. This strategy is by no means limited to translation, but also includes criticism, historiography, the anthologizing of texts, in a word, refraction, the cultural strategy that becomes operational when a text belonging to another culture is rewritten in such a way as to become acceptable to the patron, or patronage groups dominating the receiving culture at a certain point in time (Lefevere 129).

Therefore, being compelled by the untranslated novels that influenced local canonical production, I will try to discuss the Romanian novelistic translationscape as a separate 
entity from the Romanian novel. As Andrei Terian has shown, "Romanian critics' stance on translation witnessed the beginning of a new stage in history in 1918," meaning that "translations became a topic of great interest, debated not only by critics and ideologues, but also by prominent writers" and that "this period also witnessed significant improvement in the status of translations, which, although far from being officially recognized as a canonical literary category, were nonetheless included in yearly critical reports" (Terian, Translating the World 24-25). The Romanian cultural space of the early $20^{\text {th }}$ century is marked by such debates on translations stemming from various agents on the ideological spectrum. Yet what I aim for now is mapping the origins of those translated novels.

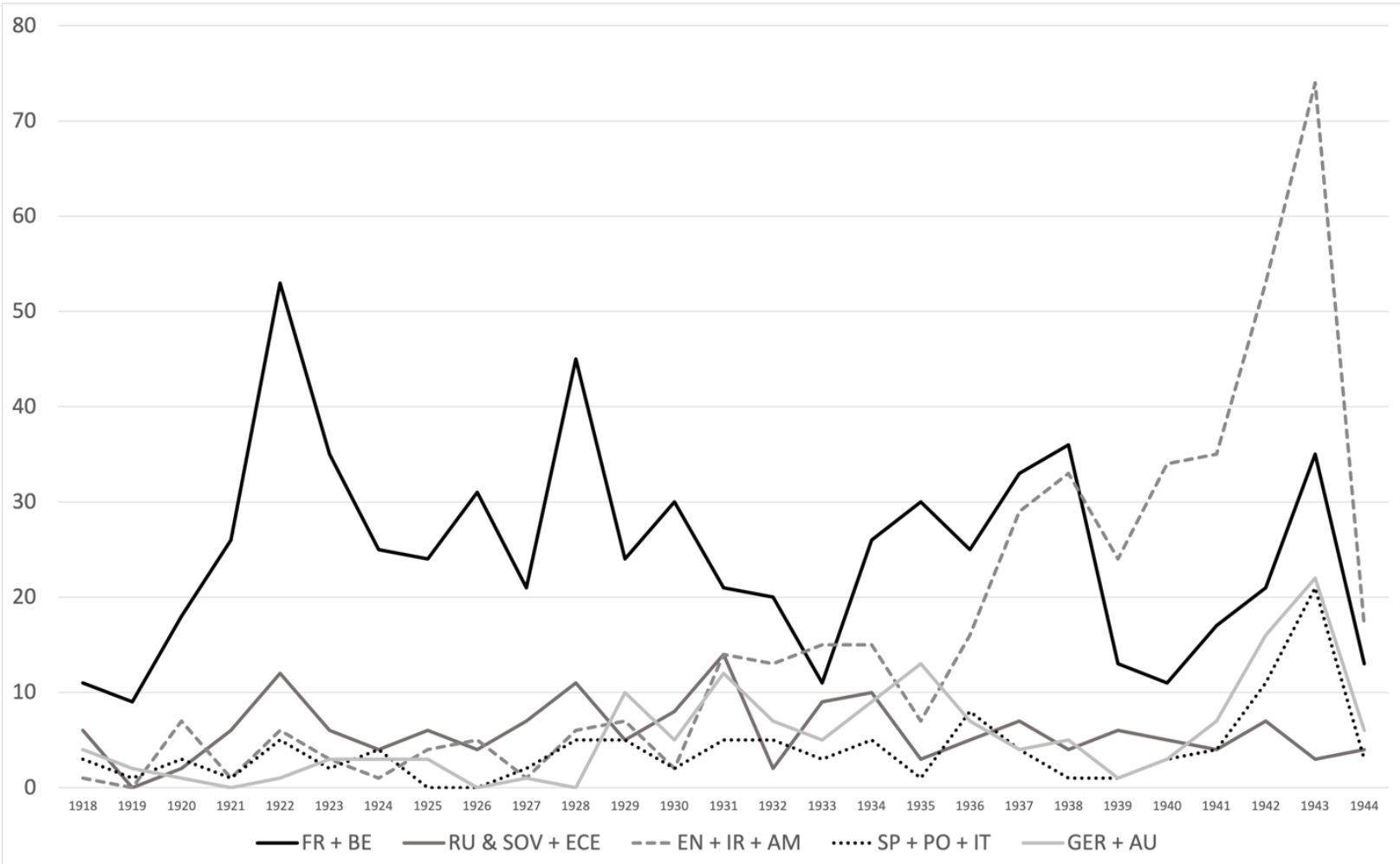

Graph 1: Main Areas (1918-1944): 1. French; 2. Russian, Soviet \& East-Central European; 3. English \& American; 4. Spanish \& Italian; 5. German \& Austrian

The methodology for this research borrows that of my earlier article on the long $19^{\text {th }}$ century (Baghiu, Translations). I have used the database of the Romanian Academy, the main Romanian resource for mapping novelistic production, Dicționarul cronologic al romanului tradus în România de la origini până la 1989 (Burlacu et al., 2005), and 
reorganized its contents on the basis of every import's country of origin. I have only taken into account complete novelistic series published in magazines (feuilletons), as well as independently published volumes - meaning that I did not take fragments or unfinished translations into account. The main reason for this, as I argued elsewhere, is that translated fragments are closer to short prose, since they function well as selfsufficient and independent pieces. It is true that they familiarize the reader with many of the worlds of the novel, yet it would be unfair to take them into account alongside other complete translations: a published fragment from Proust's ̀̀ la recherche $d u$ temps perdu does not make up for the rendition of the first volume, let alone for the translation of the entire series. In this particular case, although Proust was a very important presence in Romanian interwar literary debates, he is important - in translation - only after WW2.

\section{Proportions of imports}

\begin{tabular}{|l|l|}
\hline Source country/culture & $\begin{array}{l}\text { No. of Novels } \\
(\mathbf{1 9 1 8 - 1 9 4 4 )}\end{array}$ \\
\hline French & 664 \\
\hline English & 267 \\
\hline American (USA) & 156 \\
\hline German \& Austrian & 150 \\
\hline Russian & 108 \\
\hline Italian & 75 \\
\hline East European (Hungarian, Serbian, Czech, Polish, Slovakian) & 52 \\
& \\
\hline Nordic (Danish, Swedish, Icelandic and Norwegian) & 49 \\
\hline Spanish & 33 \\
\hline Asian (Japanese, Indian), African, Central American & 11 \\
\hline TOTAL & $\begin{array}{l}\mathbf{1 5 6 5} \\
\mathbf{( 9 0 1} \text { non-French) }\end{array}$ \\
\hline
\end{tabular}


In contrast to the 1794-1918 period, the 1918-1944 timespan can be defined especially through a decrease in the French dominance. This is strange - and completely unexpected -, since the general orientation of the critical discourse on the novel in the interwar period mainly revolved around French models. Whereas during the long $19^{\text {th }}$ century, the French novel amounts to over $70 \%$ of the absolute number of translated novels' (Baghiu, Translations 94 - see table there), during the interwar period, the proportions change dramatically. Only $43 \%$ of the translated novels are of French origin, while $57 \%$ represent non-French literatures. Of course, the French novel still accounts for almost half of translations, but nonetheless, there is a huge difference between this proportion and the dominant role it played from its beginnings up until the end of WWI. This points to the fact that we are dealing with a massive shift in the orientation of Romanian culture, especially after 1930, when English and American novels are preferred over French ones, and even more visible after 1940, when an unprecedented number of translated novels are rendered in Romanian, especially of English and American origin.

For the interwar period, in addition to the French novel - which is the main source of translations - the hierarchy is the following: 1) the top importers are no different from the $19^{\text {th }}$ century ones, but they are in a different order: The English novel - the greatest runner in the translation race -, the American novel, the German \& Austrian novel, the Russian, and the Italian novel. The changes from the long $19^{\text {th }}$ century are the demotion of the German novel and the rise of the American. 2) the peripheric cultures occurrences are the same as in the long $19^{\text {th }}$ century: East European novels (Hungarian, Serbian, Czech, Polish, Slovakian), Nordic novels (Danish, Swedish, Icelandic and Norwegian), Spanish novels, and Asian (Japanese, Indian) novels, with the addition of African and Central and South American ones - one novel for each continent, and both are debatable cases. I will thereby describe the evolution of the French novel and the evolution of two of its competitors, and that of two peripheric imports: for the competitors, I have chosen to discuss the American and Russian cases - as political narratives that are most important for socialist movements during this heavy ideologized era -; for the seldom occurrences, I will further investigate translations from Nordic cultures and Asian and African ones. 


\section{Building a French cultural "colony" and dismantling it}

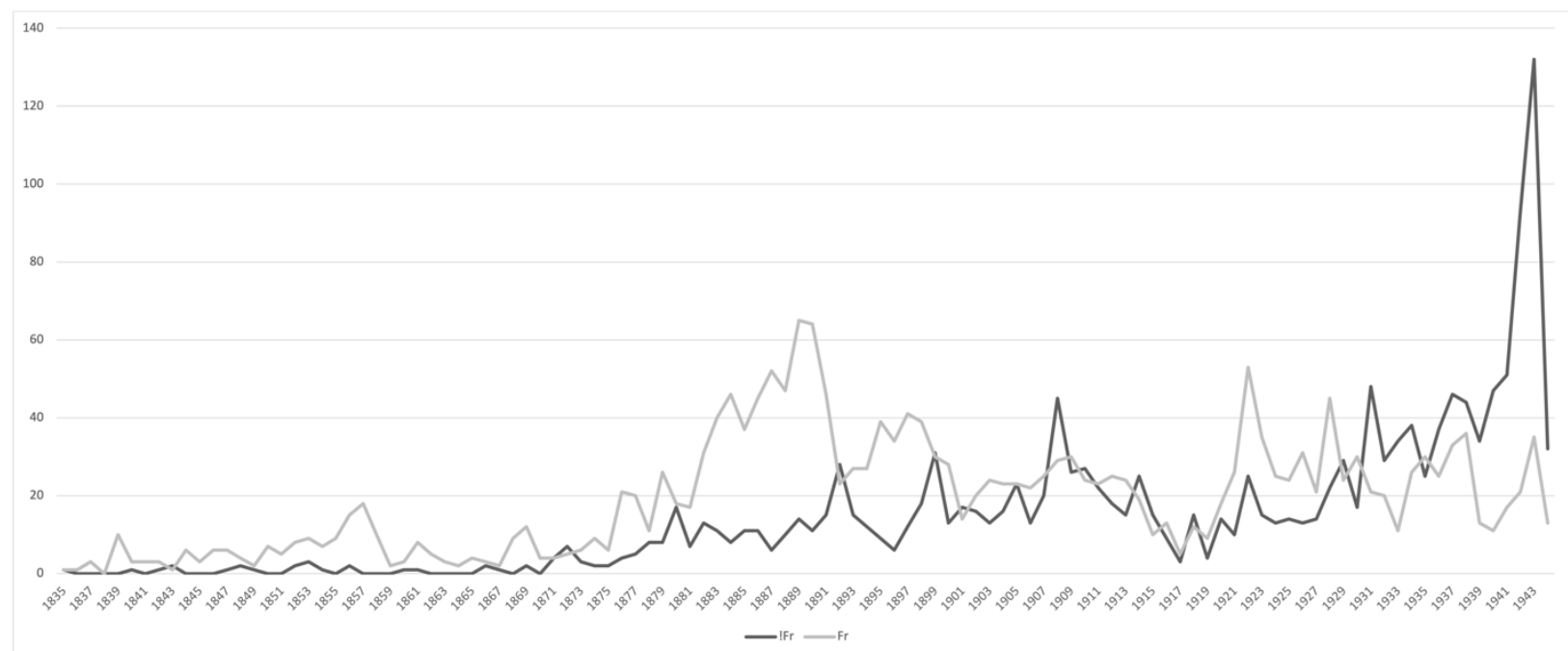

Graph 2: The Dynamics of Translation (1835-1945) between French (Fr) and Non-French (!Fr) novels

Starting with 1877, the number of renditions of French novels grew exponentially until 1890 (Baghiu, Translations), thus concluding a first wave of state-building process through imports. This period also represents one of the most important moments for French women novelists (Baghiu, "Romancierele") and for genre literature in Romanian translation (Terian et al., "Genurile romanului românesc în secolul al XIX-lea"), meaning that the first state-building phase following the War of Independence - and right before becoming a Kingdom in 1881 - requires the diverse appropriation of a monolithic culture. The French culture is - as Graph 2 shows - the main source for the local literary translation scene in respect to the novel, and non-French literatures are only soft "competitors" in this arena until 1890. The French novel is now represented by Alexandre Dumas-Père's and Jules Verne's adventure novels, Xavier de Montépin's and Alexis Bouvier's sensational novels, Pierre-Alexis Ponson du Terrail's historical fiction, and Louis Amédée Achard's “cloak and dagger” espionage novels - and, of course, many other representatives of those genres. This diverse genre dispersion merges with the Romanian genre fiction of that time. Alex Drace Francis observes an explosion of 
"paraliterary" novels, especially between 1871 and 1890, and describes "the flooding of the new market for reading matter with cheap foreign goods against the artisanal production of local petty bourgeois" (Drace Francis, The Making 165). The massive domination of translated fiction between 1877 and 1914 can also be read as a subtle strategy during the post-ottoman state-building process. Translations are now used for reaching readerships beyond the cultivated cultural elites, since those elites shared the ability of reading "good" novels in the original language. Moreover, translating less groundbreaking novels enables local authors to more easily achieve canonical status. But the dominance of the French novel in this shape and form prompted responses from all sides. The Conservative circle of "Junimea" [The Youth], led by Romanian literary critic Titu Maiorescu (1840-1917), aimed at imposing a German model in Romanian literature within the context of the new German Royal Family in Romania. Andrei Terian read this as a "compensation" process through which Romanian literature would diminish the self-colonizing tendency expressed towards French literature (Terian, National Literature 9). Subsequently, populist movements of the late $19^{\text {th }}$ century and the early $2 \mathrm{O}^{\text {th }}$ century poised themselves against depraved foreign literature and sought out a "healthy" local alternative through turning to more suitable influences. Cosmin Borza recently interpreted the translations from peripheral literatures instituted during the first decades of the $20^{\text {th }}$ century as anticolonial strategies, through which nationalist movements aimed at reducing the French dominance (Borza, Translating Against). What is clear is that the state-building process between 1877 and 1918 was based mainly on building a market. 


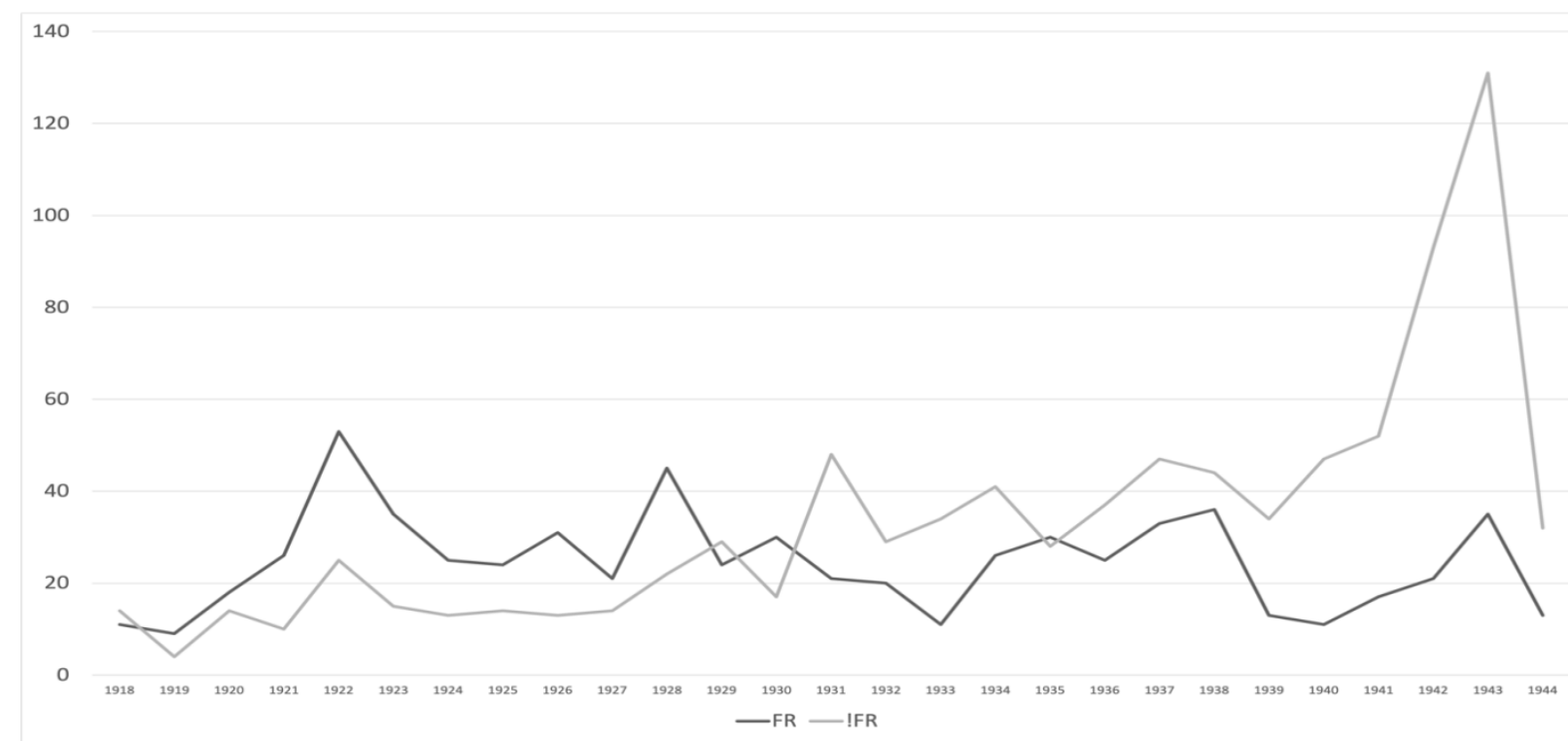

Graph 3: French and Non-French Novels (1918-1944)

Breakdown of the French influence and the rise of English and American novels

Although the French novel dominates the novelistic translationscape (Smith, Translationscapes) in Romania between 1918-1935, it must be acknowledged that the translated titles during the ' 20 s and ' 30 s are becoming quite predictable. During the entire interwar period, translating the French novel brings to the fore a perpetual déjà lu. Émile Zola, the most prominent author of this list, was already translated in 1882 , 1888 (twice), 1893, 1895 (when the most renowned female author of the time, Sofia Nădejde, translates Roma), 1896, 1897, and so on. Romain Rolland, the 1915 Nobel Prize winner, is only translated once (Colas Breugnon in 1923, with the next one, Vie de Michel-Ange, being published only in 1946). The French novel lacks innovation and trusts $19^{\text {th }}$ century genre authors to maintain the dominance in translation. To understand the inconsistent domination of the French novel, one has to know that in most Eastern European countries, the fascination with modernism during the interwar period unfolded in the absence of translations from Proust and Joyce. It is sufficient to mention that Proust's first volume of $\grave{A}$ la recherche du temps perdu was only partially translated in the late ' 20 , and that a first Romanian translation of the entire first volume can only be found in 1945 (Baghiu, The French Novel). Writers were fascinated with Proust and Gide, yet the French translationscape consisted of other authors. This is very similar to what took place in the second half of the $19^{\text {th }}$ century, when the French 
translationscape grew massively without consistent translations from Balzac or Stendhal. If we investigate the two peaks of French novel in Romanian translation from 1922 and 1928 more closely and correlate the data with the titles, we can observe that the big numbers corresponding to the French novel owe to renditions of already translated authors - seven novels by Jules Verne in 1922 and seven novels by Alexandre Dumas Pere in 1928. Authors of adventure novels and historical fiction such as Maurice LeBlanc and Victor Margueritte are often translated alongside Benoit Pierre, Louis Dumur (Swiss) and Maurice Dekobra. Far from dismissing these authors as nonimportant, I believe it is clear that the interwar literary field does, and in my interpretation, this is the main reason for the French downfall of the ' 30 s and ' 40 s. The French novel in translation now brings together new names that are rarely commented in the local press and canonical figures of genre literature. Which means that, in the moment when the Romanian translation market witnesses the downfall of French dominance, it immediately relaxes through diversifying names without deploying a particular strategy - other than a market strategy, of course. ${ }^{1}$ But those are both elitist and militant times in Romanian literary criticism, and a market strategy is not enough to counterbalance the intensive social and aesthetic debates around the novel. Except for Romain Rolland and André Maurois, no other functional names are to be found. And by functional, I mean names that elicit a palpable shift within the target culture, that change Romanian literary debates or the literary scene. Until 1935, nothing interesting happens with the French novel. Although translations from French literature looked really promising right after WWI, with Henri Barbusse's Le Feu (translated in 1918 by well-known Romanian writer and translator F. Aderca), and Zola's Nana (translated in 1918, followed by La Faute de l'abbé Mouret in 1920 and Fécondité in 1922; his reputation soon grew: 1926 saw the publication of the Romanian renditions of $L e$ Docteur Pascal, Le voeu d'une morte, and Au Bonheur des dames), the translated novels of the next few years that have been most commented are those written by Honoré de Balzac, Théophile Gautier, Victor Hugo, Alphonse Daudet, and Prosper Mérimée. The French translationscape is, between 1918 and 1944, a reiteration of a

${ }_{1}^{1}$ This brings along again, same as in the 1877-1900 period, a diverse approach to the French novel, with titles such as Aphrodite by Pierre Louÿs in 1921 or Sans famille by Hector Malot in 1922. 
prior translationscape. The translation, in 1935, of La Condition humaine - prefaced by the most renowned interwar literary critic, Eugen Lovinescu (1881-1943) - is followed by a plethora of articles discussing the "novel of negativism" and the "merchant of despair," followed in 1945 by new debates on the Resistance writers. Yet, this is the only case when French literature gains some consistent attention within the interwar translatioscape. The rise of English and American translations quickly follows suite, and other authors take centerstage.

\section{The American fascination}

The ' 30 s and '40s are mainly marked by the rise of the English and American novel during the mid ' 30 s - when a new fascination was born following the Nobel prize nomination first of Sinclair Lewis in 1930 and then of Pearl S. Buck in 1938. This helped create the image of a coherent literature - both in social and academic terms. The social - and often socialist - novels of Theodore Dreiser and Upton Sinclair - who was even challenged as writer in the US at first - were now followed by the highbrow works of new Nobel prize winners. Whereas, during the early $20^{\text {th }}$ century, The Times "panned" Dreiser's Sister Carrie and Upton Sinclair's The Metropolis (Harlan, "When the Times"), ${ }^{2}$ their later success in Europe - where the books were popular among working class readerships (Anderson, The Swedish 35-363) - was decisive for the popularity of American novels overseas. The Routledge Encyclopedia of Translation Studies indicates the new interest in English and American fiction in Romania during the '30s, doubled by a strong drive to reassess the former literary canon:

\footnotetext{
${ }^{2}$ An anonymous review in The Times in 1907 panned Sister Carrie, saying "It is a book one can very well get along without reading" and another one in 1908 panned The Metropolis claiming that "Mr. Upton Sinclair's new book is not important, it is not literature, it is not 'a good story.' To say of it that it has a sneer on every page, and on many an incendiary utterance, might be giving the author too much credit. ... It has all been done, and much better."

3 "Two contemporary American authors, however, had amassed extraordinary numbers of readers, even though they may be said to have enjoyed no reputation whatever among serious readers and the major Swedish critics. Upton Sinclair and Jack London entered Sweden through the kitchen door and factory gate and seldom penetrated to the upstairs parlors and lecture halls of «respectable» literature, yet London set new book-selling records in Sweden, and Sinclair's readers, though many fewer than London's, remained loyal for more than forty years."
} 
Other writers translated or retranslated during this period include Jules Verne, Oscar Wilde, Mikhail Lermontov, Ivan Goncharov, Rainer Rilke, Eugene O’Neill, Francois Villon, Mark Twain, Marcel Proust, and Balzac. These translations were the result of personal affinity and individual choice on the part of the translators rather than of official planning. Publishers were mainly interested in producing lucrative, popular literature. However, high quality literature could also be successful. One of the most popular authors during this period is W. Somerset Maugham: almost 30 of his titles were translated by the Romanian writer J. Giurea and published between 1930 and 1945 (Baker, Routledge Encyclopedia 538).

This process is similar to what was taking place throughout other East European cultures, which, in a similar manner, appropriate the English and American novel as shining example for local production. This is visible in the Czech translation sphere:

[t]ypical of Czech translation work between the wars was an increased interest in American literature. [...] Interest in contemporary American literature was so lively in the Czech Lands in the 1920 and 1930 s that many novels appeared in translation very shortly after the publication of the English originals. The most successful American author in Czech translation was Upton Sinclair, many of whose novels were published from 1906 onward. Also successful in Czech translation were Willa Cather, Theodore Dreiser, Scott Fitzgerald, Sinclair Lewis, John Dos Passos, John Steinbeck, Thornton Wilder and, among dramatists, Eugene O’Neill (Baker, Saldanha, Routledge Encyclopedia 382).

In Romania, publishing houses boost the American translationscape only in 1922, through translations of works by Thomas Bailey Aldrich, Jack London, and Mark Twain, yet American literature in translation gains momentum in 1925, through several consistent translations of novels written by Upton Sinclair - Jimmie Higgins, translated by socialist author Ion Pas, Iubire [Love's Pilgrimage] in 1926, Cataclismul. Roman din anul 2000 [Millenium: A Comedy of the Year 200o] in 1930, rendered by A. Mibashan, followed by a local SF imitation/tribute written by Dorina V. Ienciu in 1933, Cataclismul anului 2000 -, Petrolul [Oil] is rendered in 1931 by Mibashan, Brigada noastră [No passaran! A Story of the Battle of Madrid] is translated in 1937, and Mi se spune dulgherul [They Call Me Carpenter] appears in 1940. Upton Sinclair is by far the most 
important American author of the ' $20 \mathrm{~s}$ and ' 30 s in Romanian translation, and his success explains the enthusiastic reception of translations of novels by Theodore Dreiser and James Oliver Curwood in 1932 and 1934, respectively. After 1936, other authors gain prominence in Romania: Pearl S. Buck and Sinclair Lewis. Pearl S. Buck's Mama. Romanul vieții chineze [The Mother] is translated in 1936 by famous local author Camil Batazar, alongside Ogorul [The Good Earth]. Following her 1938 Nobel Prize, Romanian translators turn their attention towards Vânt de răsărit; vânt de apus [East Wind; West Wind], translated in 1938, and in the same year, Sinclair Lewis is rendered with his two volumes of Dodsworth.

\section{Russian dilemmas}

The most interesting aspect of translations, if we think of the political context of interwar Romania - the ban of the communist movement in 1921, the rise of far-right movements in the early 1930 - is the slow rise of Russian and Soviet narratives in translation. 1918 witnesses a highly appraised and intensely commented translation of Maxim Gorky, titled Copilăria mea [My Childhood]. In 1921, the popular fiction author N. Rădulescu Niger translates Lepădăturile societății [Creatures That Once Were Men]. Translations continue during the ' 20 s and ' 30 , alongside those of authors such as Dostoyevsky and Turgenev - marking a combined effort by both socialist and orthodox circles to accommodate the Russian populist and pre-existentialist narratives. Alexandra Kollontai's Căile dragostei [A Great Love] appears in 1927. Feodor Gladkov's Ciment [Cement] is translated by the socialist writer Ion Pas in 1930, his Pământ nou [Novaia zemlia] in 1933. Sergey Semenov's Hunger is translated during the same year Semenov being very close to the revolutionary movement of the early $20^{\text {th }}$ century and one of Gorky's intimate friends. Dmitry Furmanov's Ceapaev is translated in 1936, way before the English translation of 1940. A period of stagnation for revolutionary and Soviet translation occurs quickly after, yet translations of novels written by Ilya Ehrenburg are reestablished in 1944, when ...Şi a fost ziua a doua [Deni Vtoroi] is issued, alongside Boris Gorbatov's Neînfrânţii [Nepokorënie]. This bears, of course, witness to a striking Russian translationscape in Romania, since Mircea Martin affirmed that "in countries like Poland, in Romania there were neither favorable conditions nor earlier manifestations or anticipations of Social Realism" (Martin, Moraru, Terian, 
Romanian Literature as World Literature 241). I would rather follow Ov. S. Crohmălniceanu's description of the literary field, who claims that leftist publications such as Bluze albastre [Blue Blouses] and publishing houses could represent an interesting precedent for postwar doctrines, through "an action of support for the pacifist Congress [1932] and joining the adhesion of Bernard Shaw, Maxim Gorky, Romain Rolland, Heinrich Mann, Theodore Dreiser, Upton Sinclair, and Henri Barbusse" (Crohmălniceanu, Literatura română 148). The Bluze albastre, Şantier [Construction Site], Era nouă [New Era] magazines translated the works of revolutionary and leftist American and Soviet authors as well.

\section{The Nordic phenomenon}

Between 1918 and 1945, one of the most interesting cases of Romanian translations is that of the Scandinavian literatures. Starting with the 1919 Swedish novel The Wonderful Adventures of Nils [Nils Holgersson] by Selma Lagerlöf, originally published in 1906-1907, Nordic literature gains more and more visibility in Romanian culture. Even though, as Cosmin Borza argued, Nordic literatures entered the scene of Romanian translations even before this moment, through Romanian populists' efforts to construct an anticolonial strategy (Borza, "Translating"), the number of translated novels from Nordic literatures before 1918 is only 16, whereas during the interwar and WWII period, this number grows to almost 50 titles. Selma Lagerlöf received the Nobel Prize in 1909 and this observation, together with the ones regarding the American Nobel Prize winners, points to a multinational and geographically dispersed literary prestige translationscape. As Camille Deschamps Vierø has recently argued, Lagerlöf's novel has some ecological undertones, visible in the debates on protecting nature and in the critical engagement with exploitation and extractivism that feature throughout the book (Deschamps Vierø, "Seasons”). These narratives were popular in Romanian literature as well and as recently shown by Andrei Terian, they were responsible for the birth of early local versions of magical realism (Terian, Neoextractivism). Lagerlöf's novels are also translated in 1927 (Gösta Berlings saga), 1929, and 1931 (Ierusalim [Jerusalem]), and during the following years, her popular narratives are followed by translations from Danish authors such as Karl Adolph Gjellerup and Karl Ewald. Danish literature also consists of novels by Karin Michaëlis (Copiii din Danemarca [The Child Andrea], 1938). 
Strindberg's novel, Fiu de slujnică [The Son of a Servant], translated in 1940, is a most interesting case, since its translation, five decades after the original publishing of the first volume in the series, has to be linked to a similar Romanian novel (Fecior de slugă, 1933), by Nicolae D. Cocea (1880-1949). Starting with 1926, the Nordic novel is enriched by the rise in the translation of Norwegian novels, beginning with of Knut Hamsun's works - Pan and Foamea [Sult/Hunger], both published in 1926 -, and continuing with Johan Bojer's novels - Foamea cea mare [Den store Hunger/The Great Hunger] in 1932; Emigranții [Von Egen Stamme/The Emigrants], 1939; Cântecul prizonierului [Fangen som sang], and Din senin [Troens magt/The Power of a Lie], both in 1943. The translations from Nordic literatures reach a climax during the " 40 s through authors such as Sigrid Undset, who also won the Nobel Prize in 1928, and Finnish authors such as Frans Eemil Sillanpää and Mika Waltari - representing first contacts with Finland's novelists.

\section{Asian and African shy openings}

Asian literature started being translated in Romania first as a result of curiosity by proxy. The "exotic" extra-European exploratory novels written all throughout European colonial literatures gradually became prototypes for Romanian novelistic plots in the late $19^{\text {th }}$ century and of the early $20^{\text {th }}$ century. Regarding the translation of Asian literatures, 1921 sees the translation of Kenjiro Tokutomi's Intre moarte și iubire (Hototogisu) [The Cuckoo, 不如帰], a Japanese bestseller in late $20^{\text {th }}$ century Europe. The novel depicts the events of the first Sino-Japanese War (1894-1895) and, as it was published between 1898 and 1899, it represents a contemporary historical novel. Similarly, as it was published in Romania before the translation projects from extraEuropean and North American literatures had had time to fully mature, the novel delivers a firsthand insight into the different forms of Japanese social structures. But the main reason for its translation was, nonetheless, linked to its global circulation: "The book went through a hundred printings by 1909. By 1927, there were one hundred ninety-two printings, which added up to some 500,000 copies. There is evidence that the work attracted readers from a broad range of backgrounds" (Ito, "The Family and the Nation" 495). Similar to how the second Japanese novel translated during this time, 
Kiku Yamata's Eterna iubire. Masako [Masako], translated in 1926, provides interesting commentaries on interculturality and otherness, drawing on metaphors about "pure Asia" versus the "impure Western world" (Ames, Yamata Kiku 407). Another famous name of Asian literature, translated in 1924, is that of Rabindranath Tagore, with Bimela [The Home and the World, Ghare Baire, 1916], a similar plea for renouncing Western civilization and denouncing Eurocentrism. Of course, these three cases of translations from Asian literatures cannot alone configure a local anticolonial debate but coupled with the populist movements of the early $20^{\text {th }}$ century, formulating, through critics such as Nicolae Iorga (1871-1940), genuine attacks against Western culture, they represent forms of resistance to Western civilization, wherein the European semiperiphery draws from global peripheries both forms of resistance and reactionary pleas. Two interesting cases in the period, in addition to the translation of Asian literatures, are those of Guatemalan and South African literature. The former consists of a romanticized biography of Mata Hari (Viața, amorurile și moartea celebrei dansatoare și spioane Mata Hari, 1932 [The Life, Love, and Death of Famous Dancer and Spy Mata Hari]), written by Enrique Gómez Carrillo, classified as Guatemalan literature, although the author spent his entire life in Paris. Notwithstanding the fact that his novel addressed colonial issues, especially in regard to the relationship to Japan and the dissolution of the Ottoman Empire, the novel does not represent a precedent in the translation of literatures Central America and Latin America.

As concerns Africa, the only Romanian translation preceding the communist period is that of Caravana morții [Turning Wheels], by Stuart Cloete, published in Romanian in 1943 and in English in 1937. The novel complements a series of African and English writings about The Great Trek and as shown by Frederick Hale, it

[e]ngendered one of the most bitter controversies in South American literary history, an initially ethnic dispute which soon reached into the political arena and affected such mundane areas of life as library circulation policy and retail book sales. The strife was centred in Cape Town and, to a lesser extent, Stellenbosch, but soon spread throughout much of the Cape and had ramifications elsewhere in the Union of South Africa.

In such works as Kinders van die Voortrek by Miemie E. Rothmann (1920), Twee Voortrekkers by Pieter van der Merwe Erasmus (1935), Far Enough by Eugenie de Kalb 
(1935), They Seek a Country by Francis Brett Young (1937), Turning Wheels by Stuart Cloete (1937), and Die Wit Kraai by Anna de Villiers (1938) one finds varying degrees of authorial willingness to contribute to the heroic image of the Voortrekkers which Gustav Preller and other nationalists had carefully cultivated as a means of uplifting the morale and nurturing the ethnic cohesiveness of the urbanising volk. Occasionally the promoters of the 1938 centenary called attention to some of these literary works, especially those by Rothmann and Erasmus, and recommended them to both adolescent and adult Mrikaners seeking a deeper anchoring in their cultural heritage. (Hale, "Defending the Great Trek Myth").

The strictly contemporary perspective on translated peripheral realism (WReC, Combined and Uneven) is here noticeable. As I stressed out, alongside other scholars, in respect to the Romanian novel, the employment of the present in local narratives marks a modernization of the Romanian novel. Contemporaneity of narrative time becomes an obsession of the ' 30 s (Vancu et al., Temporalitatea). The more modern the Romanian novel becomes, the more it tends to depict contemporary events. It is interesting to witness the contemporaneity of events narrated in the peripheral novel translated in Romania, since this observation points to a double process of modernization in respect to literary imports: the geographical dispersion and the contemporary tendency.

Acknowledgement: This work was supported by a grant of the Romanian Ministry of Research and Innovation, CNCS - UEFISCDI, project number PN-III-P1-1.1-PD-20190946, within PNCDI III. (TRANOV: http://grants.ulbsibiu.ro/tranov/).

\section{References:}

Ames, Catherine. "Yamata Kiku and the Representation of a Gendered Japanese Cultural Identity.” Japan Forum 20, no. 3, 2008: 405-428.

Anderson, Carl L. The Swedish Acceptance of American Literature. University of Pennsylvania Press, 1957.

Baghiu, Ștefan. "The French Novel in Translation: A Distant Reading for Romania During Communism (1944-1989)." Transylvanian Review, XXVIII, Supplement no. 1, 2019: 83-100. 
---. "The Rise of Translations: Foreign Novels in Romania in 1877, 1945, and 1989." Transylvanian Review (forthcoming), 2021.

---. "Translating Hemispheres: Eastern Europe and the Global South Connection through Translationscapes of Poverty." Comparative Literature Studies 56, no.3, 2019: 487-503.

Baker, Mona, ed. Routledge Encyclopedia of Translation Studies. London and New York: Routledge, 2001.

Borza, Cosmin. "Translating Against Colonization. Romanian Populists' Plea for Peripheral Literatures (1890-1916)". The Culture of Translation in Romania, 2018: 31-45.

Burlacu, Doru et al. Dicționarul cronologic al romanului tradus în România de la origini până la 1989. Bucharest, 2005.

Casanova, Pascale. The World Republic of Letters. Harvard University Press, 2004.

Cohen, Margaret. The Literary Channel. The Inter-National invention of the Novel. Translation Transnation, 2001.

Cornea, Paul. Aproapele și departele. Cartea Românească, 1990.

Cotter, Sean. Literary Translation and the Idea of a Minor Romania. Boydell \& Brewer, University of Rochester Press, 2014.

Crohmălniceanu, Ov. S. Literatura română între cele două Războaie Mondiale. Minerva, 1972.

Deschamps Vierø, Camille. "Seasons Writing and Environmental Ethics in Nils Holgerssons underbara resa genom Sverige." Barnelitterært forskningstidsskrift 11, no. 1, 2020. Online. DOI: https://doi.org/10.18261/issn.2000-7493-2020-0105 .

Hale, Frederick. "Defending the Great Trek myth: Afrikaner Nationalists' campaign in the Cape against Stuart Cloete's Turning Wheels." Kronos: Journal of Cape History 26, no. 1, 2000: 102-117.

Harlan, Jenifer. "When the Times Book Review Panned the Classics," The New York Times, September 21, 2021. Online: https://www.nytimes.com/2021/o9/29/books/negative-book-reviews.html.

Ito, Ken K. "The Family and the Nation in Tokutomi Roka's Hototogisu." Harvard Journal of Asiatic Studies 60, no. 2, 2000: 489-536. 
METACRITIC JOURNAL FOR COMPARATIVE STUDIES AND THEORY 7.2

Lefevere, Andre. "Translations and other Ways in Which one Literature Refracts Another." Symposium: A Quarterly Journal in Modern Literatures 38, no. 2, 1984: 127-142.

Martin, Mircea, Christian Moraru, and Andrei Terian, eds. Romanian Literature as World Literature. New York: Bloomsbury, 2018.

Smith, Jordan A. Y. "Translationscapes: On the Legibility of Transnational Ideologies in World Literary Systems." Comparative Literature Studies 54, no. 4, 2017: 749770.

Smith, Thelma M., and Ward L. Miner. The Contemporary American Novel in France. Duke University Press, 1955.

Terian, Andrei et al. "Genurile romanului românesc (1901-1932)" [Genres of the Romanian Novel (1901-1932)]. Transilvania, no. 10, 2020: 53-63.

Terian, Andrei. "Big Numbers: A Quantitative Analysis of the Development of the Novel in Romania." Transylvanian Review, vol. XXVIII, Supplement no. 1, 2019: 55-71.

Terian, Andrei. "National Literature, World Literatures, and Universality in Romanian Cultural Criticism 1867-1947." CLCWeb: Comparative Literature and Culture 15, 5, 2013, http://docs.lib.purdue.edu/clcweb/vol15/iss5/11.

Terian, Andrei. "Neoextractivism, or the Birth of Magical Realism as World Literature." Textual Practice 35, no. 3 (2021): 485-503.

Vancu, Radu et al. "Temporalitatea internă a romanului românesc (1844-1932)." Transilvania, no. 10, 2020: 22-32.

WReC. 2015. Combined and Uneven Development: Towards a New Theory of World Literature. Liverpool: Liverpool University Press. 